\title{
AFRICAN SOLUTIONS FOR AFRICAN PROBLEMS: QUIET DIPLOMACY AND SOUTH AFRICA'S DIPLOMATIC STRATEGY TOWARDS ZIMBABWE
}

\author{
Chris Landsberg ${ }^{1}$
}

\begin{abstract}
Zimbabwe is not just a foreign policy issue for South Africa; it has become a domestic policy concern. Political, socio-economic and cultural issues have coalesced in a manner that have forced the Zimbabwe question onto the domestic agenda, and South Africa has opted to respond to the Zimbabwe challenge by way of the foreign policy strategy of "quiet diplomacy" as a form of "African solutions for African problems". This policy was associated with South Africa's former president, Thabo Mbeki, but contrary to popular perceptions, the Nelson Mandela and Jacob Zuma governments also supported this strategy, even though they claimed that they distanced themselves from it. Six years after Mbeki's departure as head of state, and into the Jacob Zuma-led presidency, the claim that there was a fundamental break with the policy of quiet diplomacy by Zuma, and that his administration pursued a fundamentally different strategy to that of his predecessor, was far-fetched. This article considers the concept of quiet diplomacy, initially seen as a form of African containment, representing methods used to first try and stop conflicts from spiralling out of control; secondly by reversing the effects of conflicts; and thirdly by rolling back conflicts by means of peaceful settlements of disputes or peace settlements; after which a country could be stabilised politically, and socioeconomically. The analysis then traces Jacob Zuma's approach towards Zimbabwe and how his new administration came to endorse and support the 2008 Global Political Agreement (GPA), which they inherited from the Mbeki government, despite the rhetoric calling for a different approach.
\end{abstract}

Keywords: Quiet diplomacy; containment strategy; African solutions to African problems; Mbeki administration; Zuma government; Government of National Unity (GNU); Global Political Agreement (GPA); road-map.

Sleutelwoorde: Stille diplomasie; inperkingstrategie; Afrika-oplossings vir Afrika-probleme; Mbekiadministrasie; Zuma-regering; Regering van Nasionale Eenheid (RNE); Globale Politieke Ooreenkoms (GPO); padkaart.

\section{INTRODUCTION}

What prompted South Africa to pursue a policy of "quiet diplomacy" towards Zimbabwe between 1998 and 2008? Was it the need to contain the deteriorating

1 Professor and Chairperson, SARChI Chair: African Diplomacy and Foreign Policy, University of Johannesburg and Senior Associate, School of Leadership, University of Johannesburg. E-mail: clandsberg@uj.ac.za 
polity and socio-economic landscape in that country? Was it the desire to ensure the survival and stabilisation of ZANU-PF and the neutralisation of the Movement for Democratic Change? Was this strategy driven by the ANC's anti-imperialist impulses and African solidarism? Was it the need to advance South Africa's PanAfricanist credentials, leadership aspirations and "African Renaissance" project that were the imperatives behind "quiet diplomacy"?

Zimbabwe has become a domestic policy concern in South Africa. Issues of forced migration; the contentious issue of an imploding economy and its impact on South Africa; the historical ties between the two countries; "liberatory" brotherhood between the ruling African National Congress (ANC) in South Africa and ZANUPF in Zimbabwe; have coalesced to prompt South Africa to opt for a foreign policy strategy of "quiet diplomacy". This was constantly presented as a form of "African solutions for African problems", the idea that Africans should be afforded the space and opportunities to devise their own solutions for their problems.

It is against this backdrop that we have to understand South Africa's choices about how it would engage Zimbabwe and other countries. This policy was associated with South Africa's former president, Thabo Mbeki, who was essentially "a policy strategist and tactician", and in particular "a foreign policy president" (Landsberg 2000). Seven years after Mbeki's departure as head of state, and into the Jacob Zuma-led presidency, it is suggested that this government would make a fundamental break with the policy of quiet diplomacy and that he would pursue a fundamentally different strategy to that of his predecessor. But did he?

Mbeki's style revealed how he sought to appreciate the complexities and nuances of foreign policy-making and governance. Given the fraternal fall-out between Thabo Mbeki and Jacob Zuma, since at least 2005 when Zuma was relieved of his duties as Deputy President and the escalation of the tension, which resulted in Mbeki's defeat as President of the ANC at Polokwane in 2007 and eventually "recalled" as head of state in September 2008, it was suggested that a Zuma-led government would come to pursue a "different", "tougher approach" vis-à-vis Zimbabwe (Landsberg 2011; see also Wolmarans 2007).

All the talk of a new strategy notwithstanding, in the end, the Zuma strategy has much in common with that of Mbeki's, even though the government was at pains to stress that they would not use the phrase "quiet diplomacy". In April 2015, President Mugabe paid a state visit to South Africa on invitation by his South African counter-part, President Jacob Zuma. This was the first such visit since 1994, again showing that, far from a hard-line approach by Zuma, South Africa actually strengthened ties with Harare during the Zuma years. When President Zuma appointed advisors Lindiwe Zulu, Charles Nqukula and Mac Maharaj as the troika of his mediation team, their strategy from the outset was to focus on national, regional and international consensus as they spoke out against violence. 
Instead of the much talked about new departure away from the Mbeki approach, President Zuma and his team inherited the 2008 Global Political Agreement (GPA) from Mbeki, and reluctantly pushed for a strategy which emphasised the need to successfully implement the GPA.

\section{OPTING FOR QUIET DIPLOMACY}

While it has been denied by all post-1994 governments in South Africa that they ever pursued a policy of quiet diplomacy vis-a-vis Zimbabwe, or any other country for that matter, reality is that, since the early days of the Nelson Mandela administration, government did in fact subscribe to this policy. Post-1994 South Africa opted to relate to fellow African states as equals and partners, not some bully on the block that would whip Africans into line, and in a famous article used by policy-makers behind the scenes, the Mandela government revealed that it believed in a policy of "quiet diplomacy" (Department of Foreign Affairs 1998:1) A 1998 Foreign Affairs document elucidated on the government's approach under the subheading "Post-1994 Quiet Diplomacy" (Department of Foreign Affairs 1998:1).

In describing the dominant approach to world affairs of the post-settlement government, this official document stated, "essentially the diplomatic activity was quiet in nature, as the department and its officials began to develop a clear understanding of the issues, as well as concrete policy positions, to further our national interests" (Department of Foreign Affairs 1998:3). It went further to opine that, "this approach was not always possible as the international community continuously placed the country in a position of leadership. The international community", it continued, "demanded and expected that South Africa's moral standing and regional strength be utilised to facilitate progress on many complex international issues" (Department of Foreign Affairs 1998:3).

Quiet diplomacy is a theory in its own right. It is an example of African solutions for African problems in practice. This notion conveys the idea that African actors should be afforded the time and space to decide on policy prescripts in seeking to address the continent's vast political and socio-economic problems. From a scholarly and theoretical point of view, "quiet" or "soft" diplomacy possess a number of characteristics, as elucidated by Graham (2006:117):

1. "Personal or direct diplomacy between heads of state or government or senior officials;

2. Little (or no) media involvement;

3. The appearance of limited action or even inaction;

4. Calm and tactful but persistent negotiation or dialogue in a non-threatening atmosphere; 
5. Constructive engagement with the target country in an effort to help solve the problems as quietly as possible;

6. Can be carried out in the context of bilateral or multilateral efforts".

This form of diplomacy enjoys a great deal of currency throughout Africa, because of its reliance on "personal and multi-lateral" forms of engagement, as well as the back-up of regional and continental institutions (Graham 2006:17).

In the African context, "quiet diplomacy" reveals something of a containment strategy. The concept "containment" of course harbours negative connotations and is closely associated both with post-World War American foreign policy and with the realist school of international relations (Ziring et al. 1995:387). Containment as applied by the Americans sought to "roll back" Soviet expansion designs. The ultimate aim of containment was "not confrontation, but accommodation". It was based on a, "well-developed, long-term, realistic theory of foreign policy" (Ziring et al. 1995:387).

Even before becoming president in 1999, Mbeki's strategic approach to foreign policy manifested itself in South Africa's posture in the Zimbabwe crisis. The political situation posed a peculiar challenge to South Africa's foreign policy; sporadic acts of violence, land invasions dubbed by the Mugabe government as fast track land restitution, eviction of farm workers, a disputed presidential election in 2002, vote-buying, vote-rigging, and various forms of human rights violations have all played themselves out in Zimbabwe. The political deterioration went with an accompanying economic meltdown. By the time Mbeki had become president, Zimbabwe witnessed a decline in virtually all key productive sectors of the economy: acute shortages of foreign exchange; massive rates of inflation; ballooning unemployment and poverty levels; and generally subdued business confidence (Stanbic Zimbabwe Group 2001). The South African government came under pressure from many quarters, most notably Britain, the United States and other Western powers to pursue a tough line against Mugabe (International Crisis Group 2002). Many constituencies at home, including some think tanks and the white-led political opposition parties, led by the Democratic Alliance (DA), also called for the adoption of draconian measures against what they described as the "Mugabe regime" (Solomon 2002). The then DA leader, Tony Leon (2003), dubbed quiet diplomacy "a failure". In 2007, Australian foreign minister, Alexander Downer, also dubbed quiet diplomacy a failure. Many powerful overseas governments, notably the United States and Britain, preferred a policy of what Mwesiga Baregu has dubbed "encirclement" of that land-locked country and ambushing of the government (Baregu 2002). The key objective of such an encirclement policy was to see not only Mugabe, but his entire government being toppled; this was in effect a policy of "regime change". 
Instead of adopting an inflexible, hardnosed stance, the Mbeki government opted for a strategy of quiet engagement: engaging Mugabe and his government, as well as members of Zanu-Pf behind the curtains through diplomatic avenues, and nudging them towards the path of "negotiations" with the opposition Movement for Democratic Change (MDC) (Stremlau 2003). In May 2000, former president Nelson Mandela came out in defence of quiet diplomacy, saying that it provided the best answer to a violent political dispute over white land ownership in Zimbabwe (The Namibian 2000). Mandela stated, "it is no use standing on hilltops and shouting about such a highly sensitive matter. An approach through diplomatic channels without much publicity is more likely to bring about a positive result". Mandela went further and said, "I would personally support President Mbeki when he says we have diplomatic relations with Zimbabwe. Everything should be done through diplomatic channels" (The Namibian 2000).

Quiet diplomacy was essentially a trade-off strategy. In exchange for offering to help resuscitate the Zimbabwean economy, addressing the land question, and to assist with negotiating an "acceptable" role for Robert Mugabe, Pretoria expected a quid pro quo in that Zanu-PF would commit itself to free and fair elections, negotiations with the MDC, and mapping out a political transition process that would "end the stand-off" in Zimbabwe (Kornegay and Landsberg 2000). Pretoria believed that calls for it to ostracise the Mugabe government and to impose limited sanctions as did the West, would not achieve this goal, and would merely result in the acceleration of the economic meltdown and political instability next door (Kornegay and Landsberg 2000).

Pretoria's strategy was also motivated by geo-strategic calculations. For the Mbeki government, there is a direct link between the conflict in Zimbabwe and the broader conflict situation in southern and central Africa (Landsberg 2002). As soon as Mbeki was inaugurated as President in June 1999, he singled out peace in the war-torn Democratic Republic of Congo (DRC) as one of his chief foreign policy goals. He also identified Zimbabwe and Rwanda as important strategic players and partners - even ally - who held significant dice in that conflict. Mugabe was a key ally of the beleaguered Laurent Kabila and Rwanda was equally a key backer of the anti-Kabila rebel groupings (Kornegay and Landsberg 2000). It had to work with Mugabe and Kagame in order to realise its strategic goals in the DRC and broader Great Lakes region.

Other factors were also at play. Contrary to conventional wisdom, South Africa did not have a lot of leverage over Zimbabwe (Kornegay and Landsberg 2000). Its leverage was circumscribed by its past and the apartheid regime's destabilising role in southern Africa prior to 1994, and its desperate efforts to make the sub-region safe for apartheid and white minority rule. Many of the Southern African Development Community's (SADC) members continue to harbour suspicions about the post- 
apartheid government's agenda, albeit that this new government was a fellow liberation movement (Rupiya 2002). The ANC-led government was hard pressed not to reinforce these suspicions. Going after Robert Mugabe's government, and threatening it with punitive measures, would have been met with a sense of suspicion and outrage on the part of not only Mugabe, but also other regional states. In addition, solidarism and the politics of camaraderie in Southern Africa, and elsewhere in Africa, make for an overriding political culture (Graham 2006). Mbeki could not afford to be seen to be acting outside of this solidarity. Breaking ranks and going it alone would almost certainly have resulted in Pretoria's isolation. Instead of ostracising Mugabe, therefore, regional states would have pursued the counter-isolation of South Africa in Southern Africa (Landsberg 2014:160).

To be sure, in private, Pretoria did express serious concern that the Mugabe government did very little to bring an end to farm invasions or to crack down on state or ZANU-PF sponsored violence and intimidation against opposition groups. By 2001 Pretoria was concerned about what it saw as the inevitable collapse of the Zimbabwean economy. At that time already, unemployment stood at $60 \%$. The economy contracted as foreign exchange equalled a few days' imports, and domestic debt was pegged at a massive R28,8 billion (Stanbic Zimbabwe Group 2001). The Gross Domestic Product (GDP) per capita, which was US\$471 in 2000 steadily worsened and total foreign debt was estimated at US\$4 billion and debt repayment was US\$ 690m behind in June 2001 (Stanbic Zimbabwe Group, 2001). Inflation reached a whopping 100\% by the end of 2001 (Stanbic Zimbabwe Group 2001). Many parts of rural Zimbabwe, notably Matabele Land and Masivingo, were experiencing serious food shortages, which hit Zimbabwe from December 2001 and got much worse by 2003 (Saburi 2003). While the Zimbabwean economy was deteriorating, the IMF determined that the country was ineligible to use IMF general resources. It was argued by some, "that more than 5 million Zimbabweans faced food shortages, and in many cases starvation, as a result of Mugabe's excesses" (Mills 2003). By mid-2003, inflation stood at an astonishing 450\% (Mills 2003). By October inflation rocketed to $619,5 \%$, and by end of December 2003 it was said that the inflation would reach $800 \%$. In 2005 , inflation had reached a crisis level of more than $1000 \%$, the highest level of any country in the world, to be followed in 2007 by an inflation rate of more than $1700 \%$. In 2011 a Centre for Conflict Resolution (CCR) report opined that the Zimbabwe economic crisis between 2000 and 2008 resulted in a fall in GDP of some 40\% (Centre for Conflict Resolution 2011:6). Hyperinflation peaked at 500 million\% in December 2008, and nominal GDP stood at a paltry \$3,5 million in 2009 (Stanbic Zimbabwe Group 2001). As a result, argued the CCR report, "living standards and life expectancy for the population of 12 million fell more rapidly than anywhere else in the world" (Adebajo and Paterson 2011:1). Many observers have also harboured the public view that the Zimbabwe crisis and 
Pretoria's quiet diplomacy was a "failure" of and setback for the celebrated New Partnership for Africa's Development (NEPAD) (Mills 2003).

While Pretoria would not express its displeasure and concerns in public, certainly not while it engaged in quiet diplomacy, in private it did express uneasiness about the unfolding crisis next door. For example, behind the scenes Pretoria-Tshwane was of the view that the "violence and intimidation", and the handling of the land reform, appeared to be the main reasons for the loss of revenue, FDI and donor support (Landsberg 2002). Pretoria also believed that it was possible to implement land reform without violence and human rights violations.

\section{MANOEUVRING FROM A TIGHT CORNER}

Pretoria believed that its own experience of land reform without violence and in violation of the rule of law was indeed possible and appropriate for Zimbabwe. It believed that Zimbabwe should be convinced of the negative ramifications of the violent take-overs of farms known as "fast-track land reform", Pretoria resorted to attempts to persuade the leadership of Zimbabwe that an end to the violence, adherence to the rule of law, and the implementation of a sustainable land reform programme was the rational way out of the crisis (Strategic and confidential documents on the Zimbabwe crisis and Mbeki's Zimbabwe strategy 2001). Presidents Mbeki and Mugabe had many discussions on the deteriorating political and economic situation in Zimbabwe; yet farm invasions continued, on top of violence and intimidation.

In another attempt to move the situation further, and in taking a leaf out of South Africa's diplomatic and foreign policy strategy, President Mbeki engaged as the go-between on Zimbabwe and the international community (Landsberg 2011). The idea was to build partnerships with key overseas partners. For example, Mbeki personally engaged the United Nations (UN) at the Millennium Summit in 2000. In response, the United Nations Development Programme (UNDP) Technical Mission, comprising internationally-renowned land-reform experts, visited Zimbabwe in October 2000 (Strategic and confidential documents on the Zimbabwe crisis and Mbeki's Zimbabwe strategy 2001). The UNDP endeavoured to bridge the gap between the position of the Zimbabwean government, who insisted that Britain and the international community should pay for the land programme, and that of the donor countries, which insisted on a credible land-reform programme by the Mugabe government before they would make available desperately needed funds. Pretoria lobbied many in the donor community, such as the European Union and the United States to support its policy and efforts (Landsberg 2011). The UK, Sweden, Norway and others pledged millions of dollars in exchange for Mugabe's government to end violence and human rights violations. With such efforts, Mbeki 
wanted to create partnerships and a bridge role, as well as a space where all parties could engage each other (Strategic and confidential documents on the Zimbabwe crisis and Mbeki's Zimbabwe strategy 2001).

In more efforts to influence developments in Zimbabwe, Mbeki established a Ministerial Task Team to engage their Zimbabwean counterparts. These included the Minister of Finance, Trade and Industry, Minerals and Energy, Land and Agriculture of both countries. Many such meetings took place in 2001. While South Africa viewed these as forums through which it could engage Zimbabwe to try and stave off both the economic and political crises, Zimbabwe viewed it as an opportunity to muster guarantees from the South African government for the selling of Zimbabwe bonds in South Africa, as they could not find a willing buyer without such a guarantee. Zimbabwe was thus not very interested in quid pro quo, or give and take (Strategic and confidential documents on the Zimbabwe crisis and Mbeki's Zimbabwe strategy 2001).

\section{APPEASING MUGABE?}

The South African government maintained a policy of sustained engagement with Zimbabwe, shrugging off what it saw as "ill-informed" calls to publicly condemn the Zimbabwean government and impose sanctions (Zimbabwe Democracy and Economic Recovery Act 2001). It stressed the importance of engaging key African strategic partners, such as Mozambique, Nigeria and the SADC, to help move the situation forward (Mail \& Guardian 2003). In September 2001 this strategy appeared to pay dividends. South Africa collaborated with Nigeria to deliver the Abuja Agreement of 7 September 2001, and President Mugabe again appeared to respond constructively. The meeting of the Committee of Commonwealth Foreign Ministers on Zimbabwe in Abuja on 6 September 2001 had present ministers from Canada, Jamaica, Kenya, South Africa, Zimbabwe and the United Kingdom, as well as the High Commissioner for Australia and the Commonwealth Secretary General (Soko and Balchiu 2009:34). They all, "recognised that, as a result of historical injustices, the pattern of land ownership and distribution needed to be rectified in a transparent and equitable manner" (Landsberg 2015).

There was further agreement that the programme of land reform must be implemented in a fair, just and sustainable manner in the interest of all the people of Zimbabwe, within the law and Constitution of Zimbabwe (Van Wyk 2002:12). Mugabe made commitments in this regard. Zimbabwe promised that "there would be no further occupation of farm lands, that farms not meeting the set criteria would be de-listed, that occupiers on unlisted farms would be moved to legally acquired land and that the rule of law to the process of the land reform programme would be 
restored" (Van Wyk 2002:12). Mugabe's government further made commitments in favour of ending violence and intimidation.

Consideration was also given to reaching an agreement with the UNDP, with a view to reaching a speedy agreement (Foreign and Commonwealth Office News 2001). International partners such as Australia, Canada and the United Kingdom undertook to engage constructively with the UNDP and the Zimbabwean government in pursuing an effective and sustainable land reform programme. These overseas partners also promised to contribute to poverty reduction programmes for the benefit of the people of Zimbabwe. The United Kingdom committed itself to a significant financial contribution to such a land reform programme but under condition that it should take place within a "legally defined framework" (Foreign and Commonwealth Office News 2001).

Mbeki steadfastly engaged sub-regional and African multilateral institutions. Pretoria-Tshwane placed confidence in SADC Summits; for example, during the SADC Summit, which took place in Malawi from 12-14 August 2001, the Heads of State decided to form a task force to work with the government of Zimbabwe on economic and political issues affecting Zimbabwe, and engaging on those issues which were impacting negatively on the whole SADC region (Southern African Development Community 2001; Africa Institute of South Africa 2001).

The Summit of the SADC Task Force on Developments in Zimbabwe was held in Harare, Zimbabwe, on 10-11 September 2001, at the invitation of President Robert Mugabe. Dr Bakili Muluzi, the then President of Malawi and Chairperson of SADC, chaired the meeting (The Economist 2001). Various stakeholders, amongst others, representatives from farmers' and trade unions, the Zimbabwe Council of Churches, the war veterans and three political parties, addressed the Summit. While many expressed discontent over the political situation in the country, almost all unanimously agreed on the need for equitable land re-distribution and pledged their support for the acquisition and distribution of land under the Land Reform and Resettlement Programme (The Economist 2001). The Southern African mediators stressed the need for national dialogue in order to find a speedy and sustainable solution to the land question in Zimbabwe.

Apart from seeking guarantees that Mugabe would stick to promises made, Mbeki's strategy also stressed the need for dialogue and negotiations between various stakeholders. For him, the impasse could only be broken through a "negotiated settlement". Just what Mbeki wanted; the Zimbabwean government and stakeholders recommitted themselves to intensify consultations aimed at confidence building and finding "lasting solutions" to the land issue, economic problems and other issues of national concern, while the political parties expressed willingness to establish a MultiParty Parliamentary Committee to discuss these issues on a continuous basis, within 
the context of the "democratic tradition of the country" (Afrika Grupperna 2003). The Summit also agreed to establish a Ministerial Task Force.

For Mbeki in turn, pacts like the Abuja Agreement were a stepping stone towards the attainment of key goals; it was part of an incremental process. In an environment of power politics, regional and continental divisions, lack of preparations and inadequate regional consultations between members of the SADC Task Force, the Abuja Agreement was viewed as a major achievement. But it was not only Mbeki who had a script; Mugabe also wrote his own script and chose the cast who would perform for the Heads of State. He would sign up to anything that would not tighten the screws against him.

\section{OF FALSE PROMISES AND DASHED EXPECTATIONS}

The UNDP Technical Mission, comprising international land-reform experts under the leadership of the UNDP Administrator, Mark Malloch Brown, was asked to intercede to try and broker a new pact on land (Mail \& Guardian 2000). This would be the start of a lot of back and forward between Harare and the UNDP with little tangible results in practice. While giving the impression of serious commitment, Mugabe was in reality buying time. The UNDP team made key proposals to President Mugabe, which included five specific commitments (Strategic and confidential documents on the Zimbabwe crisis and Mbeki's Zimbabwe strategy 2001):

1. Commencement of settlement on land already state-owned;

2. Accepting and supporting complementary approaches to land reform, such as the Karoi Initiative Project;

3. Establishing a clear, transparent and accountable mechanism to help finance the land acquisition and resettlement programme in the form of a Trust Fund;

4. Ensuring that the Trust Fund provides resources for the resettlement process, including basic infrastructure and direct compensation to farmers for land acquired;

5. Agreeing that compulsory acquisition of land shall obey rules and procedures established by law; and accepting that the overall goal will be the reduction of poverty in rural areas and as such, transparent and accountable mechanisms are needed to identify beneficiaries of the programme.

But Mugabe proved to be a shrewd and tough negotiator. He scaled down on the UNDP proposals, and only accepted a revised one which included (Strategic and confidential documents on the Zimbabwe crisis and Mbeki's Zimbabwe strategy 2001): 
1. The UNDP offered to enhance its capacity in the land reform programme;

2. Continuation of dialogue between the Zimbabwe government and other national stakeholders;

3. Establishment of a revolving fund to acquire land onto which those occupying undesignated and yet-to-be acquired land, could be moved;

4. Re-establishment of a land reform technical unit within the UNDP office in Harare but on condition that the unit assists with the current Fast Track process and does not start a new programme; and

5. Creation of a Land Reform Trust Fund to help finance the land acquisition and resettlement programme.

The Zimbabwean government thus failed to address some of the key aspects of the UNDP proposal. Harare failed to respond positively to another UNDP factfinding mission to Zimbabwe to assess the level of progress made on land reform, nor did it give any commitment that the settlement would only take place on land already owned by the state or that farmers would be compensated for land acquired (Strategic and confidential documents on the Zimbabwe crisis and Mbeki's Zimbabwe strategy 2001).

The UNDP consulted with other relevant players, including the donor community. But many donors opted for tough conditionality. Some donor countries stated that they would no longer contribute to the land reform process in Zimbabwe as long as President Mugabe remained in power.

Zimbabwe agreed to consider the proposal for an assessment team in the context of all other current initiatives on Zimbabwe, such as the Nigerian initiative on Zimbabwe/UK relations, the EU initiative, the Commonwealth Ministerial Action Group (CMAG) initiative, the OAU initiative, the SADC initiative, the EU/ACP dialogue (Article 8 of the Cotonou Agreement) the Zimbabwe Joint Resettlement initiative and the government's fast track land reform programme.

Zimbabwe also requested the UNDP to consider relief assistance to the vulnerable groups in the rural and urban areas, given the conditions of drought. In turn the UNDP agreed to consider facilitating the formulation of a programme for relief and immediate social needs of vulnerable groups in rural and urban areas for possible donor support.

Mugabe showed little seriousness about committing to their proposed solution. The UN agency subsequently began to scale down their involvement. At the Summit of the SADC Task Force on Zimbabwe on 9-10 September 2001, President Mbeki contacted UN Secretary General, Kofi Annan, requesting the UNDP to recommit itself with regard to the land reform process. Consequently, on 
11 September 2001, the UN Resident Co-ordinator to Zimbabwe proposed to the Zimbabwean government that it should allow an assessment study to be undertaken by the UNDP, in co-ordination with the Zimbabwean government, on the current resettlement levels and needs, and the formulation of a sustainable land reform and resettlement programme. Mugabe again made promises with little intention to follow them up.

As became common practice by now, Mugabe ended up snubbing the UNDP. No sooner had Mugabe promised to engage the UNDP, than it indicated in July 2001 that the assessment was no longer necessary as it was their contention that the situation had changed fundamentally from when the initial proposal was made.

\section{PLOTTING ZIMBABWE'S FUTURE THROUGH SCENARIOS}

During the Mbeki years, South Africa's Department of Foreign Affairs (DFA) and other line function ministries spent time figuring out scenarios for Zimbabwe's future. These scenarios ranged from the more middle of the road, which suggested escalation in violence condoned by the ZANU-PF government, to worst case scenarios, such as a declaration of a state of emergency.

In terms of the more plausible, middle of the road scenarios, the DFA and other departments were concerned about increasing transgressions of the rule of law, including respect for ownership and title to property, freedom of speech and association (Strategic and confidential documents on the Zimbabwe crisis and Mbeki's Zimbabwe strategy 2001). South Africa predicted unabated economic slides, heading for a minus $10 \%$ decline in GDP and increasing occurrence of general labour strikes. It was also spot on as far as predicting "severe food shortages" of maize and wheat from the last quarter of 2001. Indeed, it predicted a general destabilisation of the agricultural sector through the harassment of commercial farmers, and a mismanaged land reform policy resulting in a further decline in agricultural production (Strategic and confidential documents on the Zimbabwe crisis and Mbeki's Zimbabwe strategy 2001).

As far as Pretoria was concerned, the "fast track" land reform policies would lead to an increasing frustrated landless as result of the mismanaged land reform policy which does not meet their expectations, or lead to an improvement of their living standard (IOL). There would also be an associated escalation in internal and external displacement of the population as a result of regional food shortages, unavailability to obtain work, intimidation and harassment (Strategic and confidential documents on the Zimbabwe crisis and Mbeki's Zimbabwe strategy 2001). Dire shortage of foreign exchange reserves would curtail Harare's capacity to procure strategic imports, such as food, fuel and electricity. 
Knowing how the international financial institutions can resort to severe economic punitive measures if they are unhappy about the political directions of developing countries, Pretoria predicted that Zimbabwe would become and remain ineligible to participate in IMF and World Bank programmes. Zimbabwe would witness deteriorating human development and maintenance of infrastructure as a result of economic decline; about 300,000 Zimbabweans lost their jobs during 1999-2001 alone, and unemployment rose to $60 \%$. It was also reported that the Southern African region's economies lost about R300 billion as a result of the events in Zimbabwe and its effects on the region (Landsberg 2002).

\section{MBEKI'S ACCELERATED QUIET DIPLOMACY MOVES}

After the setbacks and the shenanigans of the Mugabe government, and fearful of these scenarios, the Mbeki government developed a three-pronged strategy: heightened bilateralism, accelerated regional engagement, and deepened international engagement (Landsberg 2002).

Bilaterally, Mbeki reached out to Mugabe's government in a more determined fashion by engaging the Mugabe government behind the scenes, so as to persuade it to withdraw from the DRC (Landsberg 2002). Mbeki also sought to convince Zimbabwe to adhere to the Abuja Agreement and to co-operate with the UNDP on the land reform process. A key objective was to convince Mugabe of the need for the 2002 presidential elections to be conducted under acceptable conditions. Mbeki also sought to convince Zimbabwe to implement the IMF recommended economic programme by, inter alia, "devaluing the official exchange rate to market related levels; limiting exchange controls; reducing the budget deficit; providing incentive packages for investors; reassuring the business community of a stable economic environment; and convincing the Zimbabwean Government that their mismanagement of the country lay at the heart of the crisis and not the land issue" (Landsberg 2015:131).

Regionally, Pretoria's strategy was to capitalise on the phenomenon of regional solidarity and partnership, and it sought to turn the SADC into a platform to try and build regional consensus on the best way to end the Zimbabwe crisis. Again, Mbeki pursued a geo-political strategy. He was convinced that he needed to work with, and engage, Southern African partners if he wished to move on Zimbabwe. More importantly, he appeared to realise "the importance of working closely with Zimbabwe and regional partners if he was to make a decisive breakthrough in the DRC” (Landsberg 2015:131).

Mbeki was even willing to toy with the idea of joint regional ventures with Zimbabwean parastatals to ensure their viability, as well as providing the SADC initiated "soft loans" to the National Oil Company of Zimbabwe (Noczim) and the 
Zimbabwe Electricity Supply Authority (Zesa) with the proviso that South Africa co-manage these entities to ensure effective management (Van Wyk 2002:2). Again, Mbeki put these ideas on the agenda in attempts to lure Mugabe en route to change.

Internationally, Mbeki viewed quiet diplomacy's strength as its ability to facilitate renewed negotiations between Zimbabwe and the Bretton Woods institutions, as well as potential donor countries. Mbeki saw South Africa as an honest broker that would lobby for international assistance to fund and "manage the land redistribution programme" in a manner acceptable to all the role players (Muleya 2003). Some of the options thrown out to Mbeki by the DFA suggested that, in the event of Zimbabwe not adhering to the Abuja Agreement, Pretoria should consider as a policy option, not discouraging the EU and US from applying "smart sanctions" against Zimbabwe. One thing is clear though: quiet diplomacy provided Pretoria with much more policy options than is readily recognised.

\section{THE \$1 BILLION CARROT TURNING POINT}

By 2005, there was an anecdote doing the rounds: Zimbabwe is South Africa's tenth province, Mugabe is its premier, and they have just submitted their budget for next year to the officials in Tshwane (Pretoria) - R6,6 billion. But the political crisis in Zimbabwe, and how to respond to it, is far more serious than this joke. A sign of the seriousness is the current dilemma faced by South Africa's decisionmakers: should Tshwane (Pretoria) or should it not bail out President Mugabe and assist the Zimbabwean government with a R6,6 billion loan to help pay off its massive foreign debt, make money available for essentials like fertilisers, fuel, medicine, petroleum, and other essentials? This is a tricky policy question which South Africa's decision makers have to answer, and the answer is complex.

The crisis in Zimbabwe is so deep that, if South Africa provides the assistance, there is no guarantee that the crisis will come to a halt; and for as long as Mugabe feels under siege, he is unlikely to heed some of South Africa's demands, such as negotiate with the opposition, end human rights abuses, and start the democratisation of Zimbabwe. Mugabe led President Mbeki up the garden path by promising to meet the (former) president half-way on many questions, but failed to do so. Quiet diplomacy's real weakness has been its inability to get President Mugabe and Zanu-PF to live up to their side of the bargain.

One of the harsh lessons learnt from the Zimbabwe crisis is that the political crisis fuelled an economic crisis, and an economic crisis fuelled a severe political crisis. So, there is need for a stabilisation of both politics and economics in that country. South Africa would be forgiven for working on the assumption that a massive loan could help stabilise the economy, which in turn would help democratise and stabilise the economy. The problem is, if South Africa fails to guarantee such a 
loan, we are almost certain to witness an accelerated meltdown next door, and South Africa will face the brunt of the spill-over. Between 2006 and 2012, we have seen sporadic acts of violence, land invasions, fast track land restitution, evictions of farm workers, disputed presidential elections, and human rights violations, combined with sanctions and the isolation of Zimbabwe, to make for a combustible cocktail that have seen the fastest declining economy in the world.

\section{A GLOBAL POLITICAL AGREEMENT - AT LAST!}

After years of painstaking and highly taxing negotiations and mediation, Mbeki could announce a major breakthrough for "quiet diplomacy"; ironically just weeks before he would be "recalled" as head of state in controversial circumstances by the ruling ANC government. Writing in August 2007, one of quiet diplomacy's main critics, Brian Raftopoulos, opined, "the current SADC-mandated mediation in Zimbabwe, led by South African president Thabo Mbeki, presents the region with a narrow window of opportunity to avoid an even greater deterioration of that country's political and economic fortunes". Raftopoulos (2007) went further to argue that, "this is an enormous undertaking, but there is a real possibility that Mbeki's current initiative will make some progress because of the lack of suitable alternatives for the incumbent regime". A number of factors combined to make the prospects for a breakthrough ripe, "the weakening of Zanu-PF as a political party; the South African government's greater sense of purpose, given its support from SADC; the rapid, cumulative decline of the Zimbabwean economy; and the opposition's preference for a peaceful settlement" (Raftopoulos 2007).

One year later, Raftopoulos appeared vindicated. On 15 September 2008, a Global Political Agreement (GPA) was signed between the then ruling ZANU-PF and the two MDC factions, led by Morgan Tsvangirai and Arthur Mutambara (African Development Bank 2013; also see Cush 2009). Under the auspices of the GPA an inclusive government was formed, and Robert Mugabe was retained as President, while Morgan Tsvangirai became Prime Minister and Arthur Mutambara was sworn in as Deputy Prime Minister (African Development Bank 2013; also see Maseng 2011).

After many stops and starts and wrangling over cabinet posts, the Government of National Unity (GNU) was eventually inaugurated on 11 February 2009. The GPA, as the name suggests, set out to be a "comprehensive" political arrangement, one which focused on many intertwined challenges that needed addressing. Key challenges that the GNU had to confront, as detailed in the "comprehensive" agreement, included the restructuring of the economy; the rule of law; lobbying the international community to drop sanctions; the land question; media reform; the drafting of the new constitution; and the promotion of national healing. The 
GPA identified the restoration of economic stability and growth as key challenges to be addressed by the GNU, and that the new fragile government launched the Short Term Economic Recovery Plan (STERP) in 2009 (Centre for Conflict Resolution 2011:2). Would Zuma commit as much time and energy to try and resolve the Zimbabwe impasse as did Mbeki?

\section{THE ZUMA GOVERNMENT AND ZIMBABWE: A CHANGE?}

Was the Zuma government's approach in any significant way different from the Mbeki government's approach to Zimbabwe? Did it signal a changed strategy, or were there greater elements of continuity? In fact, did the Zuma government have a clear strategy on Zimbabwe, or was it more a case of ad hocery?

Just because Zuma had no overt policy change, and opted instead for continuity, does not mean that there was engagement with the Zimbabwe interlocutors behind the scenes. Policy was sporadic, and the Zuma administration came to view the GPA and GNU as the end of the Zimbabwe "problem". All these assumptions need to be tested.

In the wake of the Thabo Mbeki and Jacob Zuma fall-out in 2005, and the resultant defeat at the ANC presidential election of Mbeki and Zuma's victory in Polokwane, Limpopo, during the ANC's National Congress in December 2007, many suggested that change was in the air, also in terms of foreign policy in general, and policy vis-à-vis Zimbabwe in particular (Landsberg 2015:129). The suggestion went that Zuma would come to pursue a more hard-line posture towards the Zimbabwe question, and target Mugabe in particular. The rallying cry was that "quiet diplomacy" would be abandoned and that Zuma would pursue a more forthright approach towards conflict situations in Africa (Landsberg 2015:129). Even before becoming president in 2009, Zuma himself made great fanfare of the idea that he would pursue a more hard line approach towards Mugabe and Zanu-PF. But, were these mere rhetorical flourishes intended to show-up Mbeki, or were they genuine pronouncements to show that government would embark on a fundamentally different trajectory? Zuma certainly never translated the threat to abandon quiet diplomacy into a comprehensive grand strategy.

Far from a change in approach by Zuma, "quiet diplomacy", as practised by Mbeki, was not jettisoned by Zuma. Zuma took over from Mbeki as facilitator in 2009 as soon as he became president. He appointed advisors Lindiwe Zulu, Charles Nqukula and Mac Maharaj as the troika of his mediation team (Landsberg 2015:133). By June 2011, for example, some suggested that the new President would not shy away from having "open confrontation with Mugabe" (Isaacson 2011). But the talk of a confrontational approach appeared overblown, and Deputy Minister Ebrahim Ebrahim conceded that, "there is not a fundamental 
change", and just as Mbeki used "much persuasion trying to get all the groups to act together [...] [towards] the Global Peace Agreement", the new government placed a premium on implementation of agreements reached (Isaacson 2011). So, although the new Zuma government, like its predecessors, was loath to use the label of a policy - in this case "quiet diplomacy" - it does not mean that such a policy is not being used.

As early as 27 August 2009, President Zuma embarked on a two-day working visit to Harare, and was joined by International Relations and Co-operation Minister, Maite Nkoana-Mashabane, Minister Collins Chabane, and Presidential Advisors Lindiwe Zulu, Charles Nqakula and Mandisi Mpahlwa (Department of International Relations and Co-operation 2009). Zuma made a point of meeting President Mugabe, Prime Minister Tsvangirai and Deputy Prime Minister Mutambara, as well as several Ministers; this was a direct continuation of Mbeki's strategies and tactics. Zuma stressed that the SADC and the AU remained determined to serve as, "guarantors of the implementation of the Global Political Agreement (GPA)" (Landsberg 2015:133). The Zuma government used refined and adapted versions of the GPA and turned it into a 10-point plan.

After the August 2009 visit, the South African facilitators conceded that the peace in Zimbabwe was still "fragile" as they emphasised that a major responsibility rested on the shoulders of the three leaders in the GNU - Robert Mugabe, Morgan Tsvangirai and Arthur Mutambara, as the "buck stopped with them" (Landsberg 2015:133). The "key political players [were] sending mixed messages about whether they [could] and should" be held to account" (SmithHohn 2010). Judy Smith-Hohn (2010) argued that, "Robert Mugabe has been known to renege on prior agreements" and for her, "the South African Presidency in particular had an important role to play in the elections". So what role could South Africa play?

Martin Rupiya (2010) believed that there was a necessity for "pragmatic policy options" in relation to South Africa-Zimbabwe relations, instead of "emotive policy approaches and options". According to him, the GNU in Zimbabwe was highly "fragmented" and "schizophrenic". Pretoria-Tshwane had to come up with a rational policy response, and there were "different constituencies to which South African foreign policy" needed to "respond". He particularly singled out regional actors and asserted that the "SADC had an important role to play with regards to the Zimbabwe crisis and could not be disregarded".

Instead of just censuring Mugabe, the Zuma approach recognised the need for "confidence building mechanisms" and based the "Road Map" heavily on the 2008 GPA as they negotiated with the Zimbabwe protagonists. The South African and SADC partners' new "Road Map" for peace was in reality a mini-GPA. The three protagonists of ZANU-PF and the two MDC factions played an important role in 
helping to negotiate the "The Road Map". The "Road Map", as the phrase suggests, is supposed to clear the way for fresh elections in Zimbabwe and had to address issues related to a new Constitution for Zimbabwe; establishing a conducive climate and environment for free and fair elections in the country; and agreed that the GPA would serve as the "Road Map" for a transition en route to new elections; while a Joint Monitoring and Implementation Committee (JOMIC) was agreed upon.

As stated, the GPA was refined to constitute the "Road Map", and it focussed on a number of issues that had to be addressed, including sanctions; media freedom; hate speech; rule of law; violence; a land audit and accelerated land reform; the composition of cabinet and ministerial appointments; external interference; and constitutional amendments (Zulu 2011). Contrary to the idea that the Zuma government would distance itself from Mbeki's policies, Lindiwe Zulu, Mac Maharaj and Charles Nqakula, and President Zuma became staunch defenders of the GPA and "Road Map" and encouraged all parties, the MDC included, to abide by the agreements. The South African facilitators went to the extent of turning the GPA into an "implementation matrix", which the three Zimbabwean parties were encouraged to honour (Zulu 2011). The idea was that, "a roadmap [necessitated] the implementation of all these issues [...] and [...] create an enabling environment in firstly", argued Ambassador Zulu and, "secondly we also believe that these issues if they are dealt with, if they are implemented [...] are also confidence-building mechanisms" (Zulu 2011).

Zuma certainly did not single out Mugabe for recalcitrant behaviour. For Mugabe and Zanu-PF, the issues of sanctions and the issue of non-interference were particularly sensitive and thorny, and they found a sympathetic interlocutor in the Zuma government who impressed upon Western powers the need to lift sanctions speedily. During the 2001 Southern African Liaison Office (SALO) briefing, Ambassador Lindiwe Zulu (2011) was emphatic, "we truly believe that it's time that these sanctions must be lifted". She emphasised that, "the reason why the sanctions must be lifted is because firstly, we do not believe the sanctions are having the effects they were meant to have" (Zulu 2011).

In terms of more recent engagements between South Africa and Zimbabwe, there appears to be a normalcy that has crept in in the relationship, and quiet diplomacy seems now to have been placed on the back burner. It may even be that South Africa is now simply ignoring the situation north of the border.

\section{CONCLUSION}

Quiet diplomacy, certainly as practiced by Thabo Mbeki, was an example of African solutions to African problems: the idea that African states, sub-regional and continental actors should have the right, and be "afforded the opportunity" to 
exercise the right, otherwise the phrase suggests they are beholden to some external powers to craft decisions and exercise policy autonomy as it addresses political and socio-economic challenges. It is not obvious that this remained the case under Zuma.

One of the most important lessons from Zimbabwe is that politics and economics are inextricably intertwined; you cannot resolve the one without addressing the other. Quiet diplomacy by South Africa, especially by the Mbeki government, was an attempt to contain both these crises by first arresting them, then reversing the situation, and ultimately by putting the country back on a political and economic footing. This strategy of quiet diplomacy, or engaging belligerents in a non-confrontational fashion, is one that South Africa did not only use in relation to Zimbabwe; it has been the dominant and preferred foreign policy tactic to deal with African states and political forces.

There have been two dimensions to quiet diplomacy. The one was to strategize behind the scenes on how to relate to Zimbabwe, and the other was to engage Zanu$\mathrm{PF}$ and the opposition MDC in Zimbabwe. In terms of the former, South Africa has, at least since 1996, harboured serious concerns about what it perceived as the mismanagement of the Zimbabwean economy and signs of a political deterioration. The Zimbabwean government often accused Pretoria of "a conspiracy" and Western inspired plot. Mugabe proceeded to question South Africa's commitment to the SADC.

Since President Mbeki first became involved in efforts to solve the land question and political impasse in Zimbabwe, South Africa faced a double-edged dilemma. On the one hand, it had to work within the framework and constraints of the SADC and broader African diplomacy; it could not go it alone. On the other hand it had to contend with what it saw as Harare's half-truths, double speech, broken promises and delay tactics. Pretoria had to contend with the reality that Harare's stalling tactics could undermine regional political manoeuvres, and Mbeki's quiet diplomacy strategy could be discredited as a mere pipe dream. Pretoria's strategy faced a major hurdle: while Mbeki was genuinely committed to his constructive engagement approach, Mugabe was not really interested in a solution. There was almost a dialogue of the deaf between Pretoria and Harare.

Behind the scenes, Pretoria held the view that Mugabe's failure to heed South Africa's fraternal counsel led to their economy going into free fall. Mugabe's stubbornness also emboldened those in favour of smart sanctions. A key problem with quiet diplomacy is that it did not appear to realise that, for as long as there is great international polarisation over Zimbabwe, in which "white" European and American governments would pull in the direction of punitive measures, and "black" African governments would pull in the direction of solidarity and closing ranks in defence of the Zanu-PF government, then the impasse in Zimbabwe would 
persist. Quiet diplomacy placed Mbeki and his government in a strong position to push for an international consensus over the need for a transition in Zimbabwe.

The Zuma government built on what they inherited from his predecessor, rhetoric to the contrary notwithstanding. Zuma never really confronted Mugabe and therefore never really followed through on his threat, and instead of change and discontinuity, the policy showed high degrees of continuity and similarity with the approach pursued by Mbeki.

\section{LIST OF SOURCES}

Adebajo, A and M Paterson 2011. "State reconstruction in Zimbabwe", Policy Brief 9. OSISA, <http://www.osisa.org/sites/default/files/sup_files/State\%20Reconstruction $\% 20$ in $\% 20$ Zimbabwe $\% 20-\% 20$ Centre $\% 20$ for $\% 20$ Conflict $\% 20$ Resolution.pdf $>$, accessed 30 November 2015.

African Development Bank 2013. Zimbabwe: Country Brief 2011-2013, <http://www. afdb.org/fileadmin/uploads/afdb/Documents/Project-and-Operations/ Zimbabwe\%20 Country\%20Brief\%20June\%202011.pdf>, accessed 30 December 2011.

Africa Institute of South Africa (AISA) 2001. Current Affairs Briefing 35:1-6.

Africa News Service 2002. "Farmers fight for survival on land", 24 July.

Afrika Grupperna 2003. Zimbabwe, 11 March, <www.afrikagrupperna.se/ fakta/ regionen/Harare.htm>.

Baregu, M 2002. "The role of SADC in resolving the crisis". Paper presented at the International Peace Academy Seminar on Democracy and Land Reform in Zimbabwe, New York, 25 February.

Centre for Conflict Resolution 2011. State reconstruction in Zimbabwe. Policy Seminar Report, Siavonga, Zambia, 9-10 June.

Cush, IK 2009. "Inclusive government for Zimbabwe next week", New York, Amsterdam, News/10591818, 20090205.

Department of Foreign Affairs 1998. Overview of the Work Programme of the Department of Foreign Affairs, Pretoria.

Department of International Relations and Co-operation 2009. "President Jacob Zuma arrives in Zimbabwe on a working visit", Media release, 27 August.

Dlamini, K, G Mills and N Grobbelaar 2001. "Rethink quiet diplomacy in Zimbabwe", Mail \& Guardian, 9 May, <http://archive.mg.co.za/NXT/gateway.dll. PrintEdition/MGP2001/31v02762/41v03003/51v>, accessed 9 May 2001. 
Foreign and Commonwealth Office News 2001. "Conclusions of the meeting of the Committee of Commonwealth Foreign Ministers on Zimbabwe", Abuja, Nigeria, September, <http://www.publications.parliament.uk/pa/cm200102/cmselect/cmfaff/ 456/moex05.htm>, accessed 18 January 2016.

Graham, V 2006. "How firm the handshake? South Africa's use of quiet diplomacy in Zimbabwe from 1999 to 2006", African Security Review 15(4):114-127.

IOL 2015. IOL Breaking News, <www.iol.co.za>

International Crisis Group 2002. "All bark and no bite? International response to Zimbabwe's crisis", Report 25, January, $<\mathrm{http}$ //www.crisisgroup.org/en/regions/africa/ southern-africa/zimbabwe/040-all-bark-and-no-bite-the-international-response-tozimbabwes-crisis.aspx>, accessed 30 November 2015.

Kornegay, F and C Landsberg 2000. "Mbeki in a cleft stick over Zimbabwe", Sunday Independent, 14 May.

Kornegay, F and C Landsberg 2000. The Citizen, 23 June.

Landsberg, C 2000. "The African diplomacy of giantism? Comparing the foreign policies of Mbeki's South Africa and Obasanjo's Nigeria”. Paper presented at the $40^{\text {th }}$ anniversary conference of the Africa Institute of South Africa (AISA), Pretoria.

Landsberg, C 2002. “Thabo Mbeki's quiet diplomacy gets noisy”. Paper presented at the International Peace Academy Seminar on Democracy and Land Reform in Zimbabwe, New York, 25 February.

Landsberg, C 2011. "Transformation, continuity and diffusion: South Africa's foreign policy under Thabo Mbeki and Jacob Zuma", Inroads 29, <http://inroadsjournal.ca/ transformation-continuity-and-diffusion-south-africas-foreign-policy-under-thabombeki-and-jacob-zuma/>, accessed 18 January 2016.

Landsberg, C 2014. "The concentric circles of South Africa's foreign policy under Jacob Zuma”, India Quarterly 70(2):153-172.

Landsberg, C 2015. "Sub-continental entente: Twenty years of South Africa's SADC strategy". In: Lesley Masters, Jo-Ansie van Wyk, Siphamandla Zondi and Chris Landsberg (eds), South African Foreign Policy Review. Volume 2, Pretoria: Africa Institute of South Africa, pp. 119-142.

Leon, T 2003. "Roadmap to democracy in Zimbabwe". The South African Institute of International Affairs (SAIIA), 2 December.

Mail \& Guardian 2000. "Mbeki washes his hands of the problem", 15 December. 
Mail \& Guardian 2003. "Nigeria denies rift with Mbeki over Zim", 16 March, Mail \& Guardian Online, <news.biafranigeriaworld.com/archive/2003/mar/16/0100.html>, accessed 16 June 2012.

Maseng, JO 2011. "Zimbabwe's inclusive government", Pambazuka News: PanAfrican Voices for Freedom and Justice, 26 January, <http://pambazuka.org/en/ category/comment/65774>.

Mills, G 2003. "Taking stock of quiet diplomacy”, Business Day, 3 October.

Muleya, D 2003. "Mbeki defends quiet diplomacy stance", The Zimbabwe Independent, 21 November, $<$ http://www.theindependent.co.zw/news/2003/November/Friday21/ 1420. html $>$, accessed 16 June 2012.

Raftopoulos, B 2007. "Staring down the barrel”, Global Dialogue 12(2):16-17.

Rupiya, M 2002. "Eight years of tension, misperception and dependence from April 1994 to December 2001 Zimbabwe-South Africa foreign relations: A Zimbabwean perspective", Alternatives 1(4):147-157.

Rupiya, M 2010. "South Africa's foreign policy options in relation to the transition government in Zimbabwe". Paper delivered at the SALO Policy Dialogue on South Africa's Relations with Zimbabwe, Report No. 4, University of Johannesburg, 17 November.

Saburi, H 2003. "Free-falling exports push Zim deeper into recession", FinGaz, 22 May, $<\mathrm{http}: / /$ www.zimbabwesituation.com/may24_2003.html $>$, accessed 30 November 2015.

Soko, M and N Balchiu 2009. "South Africa's foreign policy towards Zimbabwe: a nexus between foreign policy and commercial interests?", South African Journal of International Affairs 16(1):33-38.

Southern African Development Community (SADC) 2001. "SADC Summit Final Communique", SADC Summit, Blantyre, Malawi, 14 August, <www.sadcint/files/ 3913/5292/8384/SADC_Sum>, accessed 16 July 2014.

Stanbic Zimbabwe Group 2001. "State of the Zimbabwean economy", Outlook, 6 November:1-18.

Solomon, H 2002. "South African foreign policy, preventive diplomacy and the false promise of conflict resolution", South African Journal of International Affairs $9(2): 147-157$.

Strategic and confidential documents on the Zimbabwe crisis and Mbeki's Zimbabwe strategy 2001. Shared with the author by the Department of Foreign Affairs, Pretoria. 
Stremlau, J 2003. "Mbeki's softly, softly stance on Zimbabwe in SA's best interests", Sunday Times, 21 September, <www.allAfrica.com/stories/200309220272.html>, accessed 18 January 2016.

The Economist 2001. "Zimbabwe: the pressure builds", 15 September, pp. 41-42.

The Namibian 2000. "Mandela urge quiet diplomacy on Zimbabwe crisis", 6 May, quoted in Chris Landsberg, "Sub-continental entente: Twenty years of South Africa's SADC strategy". In: Lesley Masters, Jo-Ansie van Wyk, Siphamandla Zondi and Chris Landsberg (eds), South African Foreign Policy Review. Volume 2, Pretoria: Africa Institute of South Africa, 2015, p. 141.

Smith-Hohn, J 2010. "2011 Elections and lessons from South Africa's transition”.. Paper delivered at the SALO Policy Dialogue on South Africa's Relations with Zimbabwe, Report No. 4, University of Johannesburg, 17 November.

Van Wyk, J 2002. "The saga continues: The Zimbabwe issue in South Africa's foreign policy”, Alternatives 1(4):176-231.

Wolmarans, R 2007. "Zuma on Zim, Mbeki and corruption", Mail \& Guardian, $<$ http://mg.co.za/article/2007-12-20-zuma-on-zim-mbeki-and-corruption>, accessed 18 January 2016.

Ziring, L, JC Plano and R Olton 1995. International Relations: A Politics Dictionary, Santa Barbara: ABC-Clio.

Zulu, L 2011. "Perspectives on a roadmap for Zimbabwe". Address to the SALO Workshop, Burgers Park Hotel, Pretoria, 9 May.

\section{Interview}

Isaacson, Maureen 2011. Journalist of the Sunday Independent. Interview, 3 July. 